\title{
Oceanography
}

CITATION

Arthurs, L. 2016. Course design principles for enhancing student learning.

Oceanography 29(4):207-208, https://doi.org/10.5670/oceanog.2016.93.

DOI

https://doi.org/10.5670/oceanog.2016.93

COPYRIGHT

This article has been published in Oceanography, Volume 29, Number 4, a quarterly journal of The Oceanography Society. Copyright 2016 by The Oceanography Society. All rights reserved.

USAGE

Permission is granted to copy this article for use in teaching and research.

Republication, systematic reproduction, or collective redistribution of any portion of this article by photocopy machine, reposting, or other means is permitted only with the approval of The Oceanography Society. Send all correspondence to: info@tos.org or The Oceanography Society, PO Box 1931, Rockville, MD 20849-1931, USA. 


\section{Course Design Principles for Enhancing Student Learning вy lelaniarthurs}

Myriad variables affect what and how students learn. An individual instructor has little influence over most of these variables; nevertheless, how an instructor designs a course is within his/her sphere of influence. Before we consider course design principles for enhancing student learning, I invite you to close your eyes and imagine the following scenario: You need to get to a conference where you are presenting recent research findings. How are you going to get there? How much time do you have to get there? How much of your budget will cover transportation?

In this scenario, how do you approach getting to the conference? If you are like most conference attendees, the first thing you do is set the goal of getting to the conference on time and within budget. Second, you likely implicitly form a mental list of assessment criteria that informs an effective travel plan. For example, what constitutes being on time, and what is within budget? Third, you apply that mental list of assessment criteria to design a plan of travel that helps you attain the initial goal you set.

We can draw parallels between this kind of planning for a trip and planning for a course designed to facilitate deep student learning. A useful framework for planning such a course is called "backward design" (Wiggins and McTighe, 2005). This concept is grounded in three principles: (1) establish learning goals, (2) determine what constitutes acceptable evidence of learning, and (3) plan appropriate learning opportunities.

This planning scheme is called backward design because instructors often do not begin with defining the learning goals for students in their courses. Instead, they often jump directly to what they will do (e.g., give a lecture, do a demonstration).
Using backward design as a framework for course design requires resisting the temptation to go straight to doing things and instead take a step back to first think about and explicitly plan out what we want students to be able to do and how we will assess their progress. In this way, we are able to design courses whose learning goals, assessments, and activities are well aligned with one another and therefore more effectively support student learning.

After evaluating her own approach to teaching, this description of a poorly aligned course came from a member of the University of Nebraska's Academy of Distinguished Teachers, Christine Marvin, who said:

I was amazed and embarrassed to discover that I had course learning goals I never taught, I had learning goals I taught but never assessed, I had learning goals I assessed and never taught, and I had material I taught and assessed but never listed as a course learning goal. By reorganizing the learning goals of my course, developing rubrics for evaluating student work, and assessing my classroom activities, I now have a focused approach for linking my teaching to my students' learning. (Savory, 2012)

Below are brief guidelines for writing learning goals, and resources for assessments and learning activities as a means of providing readers with leads to learn more about these areas.

Establish learning goals. Establishing learning goals involves articulating the desired results of learning. That is, what do we want students to be able to do as a product of participating in our courses? Unlike the key concepts listed in a syllabus, learning goals communicate more precisely what students will be able to do with respect to said concepts. A wellarticulated set of learning goals is a valuable course design tool for instructors because it provides the foundation for developing appropriate assessments of learning as well as appropriate learning activities that facilitate student attainment of those goals.

Basic guidelines for creating a learning goal include the following:

1. Begin with "At the end of the topic/ unit/module/course, students will be able to..."

2. Use specific verbs and language related to the desired result to complete the statement above (i.e., the goal is not vague).

3. Make sure the goal is assessable (i.e., you can think of a corresponding assessment item).

4. Factor in what students will be able to do and at what level they will be able to do it (be sure to include higher-order thinking skills, even in introductorylevel courses).

Bloom's taxonomy of the cognitive domain (Bloom, 1956), or its subsequent revision (Krathwohl, 2002), provides a useful framework for writing learning goals (and assessment items). The different levels in the taxonomy of the cognitive domain represent a range from lowerorder to higher-order thinking skills (see Figure 1). Keep in mind that learning goals that address higher-order thinking skills are inevitably linked to underlying lower-order thinking skills. For example, it is not possible to make a reasoned weather forecast (higher-order thinking skill) without knowing basic knowledge of weather (lower-order thinking skill).

Determine what constitutes acceptable evidence of learning. Once learning goals are established, assessments 
that evaluate the extent to which students achieve the learning goals can be developed and/or identified. While Table 1 provides key words that can be used to craft original assessment items, there may already exist assessment instruments that are well aligned with the learning goals of your course and/or that you can adapt to suit your course needs. For example, if your course incorporates physics and/or chemistry concepts to a large extent, you might consider examining the following assessments to determine whether or not they may be appropriate for assessing student learning in your course:

- Force Concept Inventory (FCI): http://modeling.asu.edu/R\&E/ Research.html
- Chemical Concepts Inventory (CCI): http://modeling.asu.edu/ModChem_ web/Evaluation/CCI-old/ ChemConcepts Inventory-JCE.pdf

- Other field-tested assessments can be found at http://www.flaguide.org/ intro/intro.php

\section{Plan appropriate learning opportuni-} ties. Although lecture is a time-honored tradition in undergraduate and graduate classrooms, research in brain science and the learning sciences indicate that lecture alone is insufficient for deep learning (Schwartz and Bransford, 1998). Other research indicates that as little as $10 \%$ of class time dedicated to active learning strategies enhances student learning
(Freeman et al., 2014). Useful online resources for learning more about a variety of active learning strategies include, for example:

- Science Education Resource Center at Carleton College: http://serc.carleton. edu/serc/search.html?search_text= oceanography\&endpoint $=$ Fserc Fsearch.html

- Digital Library for Earth System Education: http://www.dlese.org/ library/query.do?q=oceanography\&s= $0 \& g r=0 a \& g r=01$

- Field-tested Learning Assessment Guide: http://www.flaguide.org/cat/ cat.php

The three online resources listed here include a plethora of ideas for activities that involve students in their learning.

A well-aligned course can facilitate deep learning, especially when it includes opportunities for students to actively engage with the course material, peers, and the instructor. In closing, I'd like to leave you with a quote attributed to Benjamin Franklin, "Tell me and I forget, teach me and I may remember, involve me and I learn.” @

\section{REFERENCES}

Bloom, B.S. 1956. Taxonomy of Educational Objectives: The Classification of Educational Goals. Handbook 1: Cognitive Domain. McKay, New York.

Freeman, S., S.L. Eddy, M. McDonough, M.K. Smith, N. Okoroafor, H. Jordt, and M.P. Wenderoth. 2014. Active learning increases student performance in science, engineering, and mathematics. Proceedings of the National Academy of Sciences of the United States of America 111(23):8,410-8,415 https://doi.org/10.1073/pnas.1319030111.

Krathwohl, D.R. 2002. A revision of Bloom's taxonomy: An overview. Theory into Practice 41(4):212-218, https://doi.org/10.1207/s15430421tip4104_2.

Savory, P. 2012. Making teaching and learning visible. Discipline-Based Education Research Group Speaker Series. Digital Commons, University of Nebraska-Lincoln, April 3.

Schwartz, D.L., and J.D. Bransford. 1998. A time for telling. Cognition and Instruction 16(4):475-523, https://doi.org/10.1207/s1532690xci1604_4.

Wiggins, G.P., and J. McTighe. 2005. Understanding by Design, $2^{\text {nd }}$ ed. Association for Supervision and Curriculum Development, Alexandria, VA, 370 pp.

\section{AUTHOR}

Leilani Arthurs (larthurs2@unl.edu) is Assistant Professor, Department of Earth and Atmospheric Sciences, University of Nebraska-Lincoln, Lincoln, NE, USA.

\section{ARTICLE CITATION}

Arthurs, L. 2016. Course design principles for enhanc ing student learning. Oceanography 29(4):207-208, https://doi.org/10.5670/oceanog.2016.93. 